\title{
Sources of error in the biochemical diagnosis of muscular dystrophy ${ }^{1}$
}

\author{
W. H. S. THOMSON \\ From the Department of Biochemistry, the Western Infirmary, Glasgow
}

Muscular weakness due to classical disease is readily diagnosed; when symptoms are vague, signs equivocal, and the history confused much difficulty may arise. Walton (1956) has reviewed the use in diagnosis of examination of the cerebrospinal fluid, muscle biopsy histology, and electromyography. More recently, assay of the serum enzymes aldolase, glutamic-oxalacetic and glutamic-pyruvic transaminases has proved valuable in distinguishing neurogenic muscular weakness from that due to intrinsic muscle disease.

Serum enzyme activities are normal in patients with neurogenic weakness, but are raised, sometimes grossly, in those with muscular dystrophy (Schapira, Dreyfus, and Schapira, 1953; Sibley and Fleisher, 1954; Jacob and Neuhaus, 1954; Dreyfus and Schapira, 1955; Beckmann, 1956; Aronson and Volk, 1956; Siekert and Fleisher, 1956; Evans and Baker, 1957; White and Hess, 1957; Salvi, Ambanelli, Rosati, Carreras, and Mironi, 1959; White, 1959; Kaeser, 1959; Aronson, 1960). These elevations seem due to cellular efflux (Thomson, Leyburn, and Walton, 1960) and are greatest by far in the Duchenne type of dystrophy. The highest values occur in early childhood, diminish as the disease progresses, and are least raised terminally (Schapira, Demos, Schapira, and Dreyfus, 1957; Aronson and Volk, 1957a; Pearson, 1957; Rowland and Ross, 1958; Murphy and Cherniak, 1958; Gentili, 1959; Breton, Gaudier, Traisnel, and Ponté, 1959; Thompson and Vignos, 1959; Kaeser, 1960; Thomson et al., 1960).

These diminutions accompany the disappearance of skeletal muscle. Thus in the Duchenne type of dystrophy there is a linear relationship between serum aldolase activity and functional muscle mass (Thompson and Vignos, 1959) or age of the patient (Thomson et al., 1960) in accord with an early onset (Pearson, 1961a) and a constant, rapid evolution (Walton and Nattrass, 1954). Similar, less striking relationships occur (Thomson et al., 1960) in the

${ }^{1}$ This work was aided by a research grant from the Muscular Dystrophy Group of Great Britain, and a preliminary report has appeared in the Proceedings of the Association of Clinical Biochemists (1961, 1, 79). more benign facio-scapulo-humeral type and in dystrophia myotonica but not in the limb-girdle type with its variable individual progression (Walton and Nattrass, 1954).

In the Duchenne type of dystrophy serum aldolase activity declines less smoothly with age in young active patients than in those physically disabled (Thomson et al., 1960), and the wide individual variations found in ambulant children (Thompson and Vignos, 1959) disappear only when they become bedridden (Schapira et al., 1957).

The effects of rest and exertion on the serum enzymes aldolase, glutamic-oxalacetic and glutamicpyruvic transaminases have now been examined in various types of muscular dystrophy. The results are discussed to prevent errors in biochemical diagnosis, and further useful information is included.

\section{METHODS}

DIPHOSPHOFRUCTOALDOLASE $1:$ :-Diphosphofructoaldolase, found in normal serum, is an intracellular glycolytic enzyme abundant in skeletal muscle, $300 \mathrm{mg}$. of which contains as much as the entire adult circulation (Sibley and Fleisher, 1954).

Aldolase reversibly splits D-fructose-1: 6-diphosphate (FDP) into equimolecular amounts of the trioses D-glyceraldehyde-3-phosphate (G-3-P) and dihydroxyacetone phosphate (DAP), and is estimated colorimetrically (Sibley and Lehninger, 1949; Evans and Baker, 1957; Friedman and Lapan, 1958) by triose production measured as alkaline osazone, or enzymatically (Beisenherz, Boltze, Bücher, Czok, Garbade, Meyer-Arendt, and Pfleiderer, 1953; Slater, 1953) by coupled systems dependent on reduced diphosphopyridine nucleotide (DFN-H).

In the enzymatic method, used throughout ${ }^{2}$, triose formed is converted by excess added triose phosphate isomerase to DAP, thence to glycerophosphate by DPN-H and glycerophosphate dehydrogenase. The rate of change of optical density of the system at $340 \mathrm{~m} \mu$ measures conversion of DPN-H to DPN by DAP produced, and thus the serum aldolase activity which is

${ }^{2}$ Standardized reagents for the enzymatic method were supplied by C. F. Boehringer of Mannheim (British agents: Courtin \& Warner, Lewes, Sussex). 
reported as $\mu \mathrm{l}$. of FDP split per hour by $1 \mathrm{ml}$. of serum at $37^{\circ} \mathrm{C}$. (Bruns, 1954).

All readings were taken in a thermostatic cell chamber against serum in normal saline. After adding serum to the reagents at $37^{\circ} \mathrm{C}$. in the photometric silica cell, five minutes were allowed for serum lactic dehydrogenase to equilibrate traces of serum pyruvate with DPN-H (Karmen, 1955). Final calculations were made from straight-line graphs of optical density against time. Serum of very high activity was diluted with normal saline, a method proved by testing serial dilutions. Serum retained its aldolase activity for at least a fortnight at $-17^{\circ} \mathrm{C}$.

TRANSAMINASES Transaminases are also intracellular enzymes abundant in skeletal muscle and found in normal serum.

Serum glutamic-oxalacetic transaminase (SGOT) reversibly converts aspartic and $\alpha$-ketoglutaric acids to oxalacetic and glutamic acids, and serum glutamicpyruvic transaminase (SGPT) similarly alanine to pyruvic acid. Assay may be enzymatic (Karmen, 1955; Karmen, Wróblewski, and LaDue, 1955; Wróblewski and LaDue, 1956) by coupled DPN-H-dependent systems, or colorimetric (Reitman and Frankel, 1957) by measuring the alkaline $2: 4$ : dinitrophenylhydrazone of the reaction product.

In the colorimetric method, used throughout ${ }^{3}$, the optical density, at $505 \mathrm{~m} \mu$ against water, of the alkaline 2:4-dinitrophenylhydrazone is converted from a standard graph to units of enzyme activity per millilitre of serum, corresponding to those defined by Karmen (1955).

As before, serum of very high activity was diluted with normal saline, a method similarly found valid. Serum transaminase activity remained intact for more than a fortnight at $-17^{\circ} \mathrm{C}$.

The normal ranges are those found by Rowell and Smith (1959), using similar methods, in 50 healthy adults, and for serum aldolase are 2.3 to 8.8 units per ml. (mean 5.7 units), for SGOT 12 to 36 units per ml. (mean 19 units), and for SGPT 4 to 24 units per ml. (mean 12 units).

In the figures (except Figs. 4, 5, and 6) the activity of serum aldolase is denoted by an uninterrupted line, of SGOT by long strokes, and of SGPT by short strokes.

\section{CLINICAL MATERIAL}

All cases were clearly identified as specific myopathies by the rigid clinical criteria of Walton and Nattrass (1954).

DUCHENNE-TYPE MUSCULAR DYSTROPHY This was studied in subjects of a wide range of ages.

Effects of rest and exercise in ambulant boys For one week each child was rested though free to move in bed (Whedon, 1952). He was then allowed up as usual on two successive mornings, returning to bed at 6 p.m.; next day he was discharged.

Figure 1 (boy aged 7 years) illustrates the active early

${ }^{3}$ Standardized reagents for the colorimetric method were supplied by the Sigma Chemical Co., St. Louis, U.S.A. (British agents: G. T. Gurr, London). stages with minimal signs and disability; Fig. 2 (boy aged 11 years) a more advanced stage with lumbar lordosis and a noticeable waddle; and Fig. 3 (a boy aged $9 \frac{1}{2}$ years) the barely ambulant stage, despite his years, with marked lordosis, a rolling gait, and early contractures.

Relationship of serum enzyme activities to age The ages at casual venepuncture of 24 male patients, from active boys to helpless men, were not taken in round years, but to the nearest day, and clinical status was denoted by circular points for full ambulation and triangular for permanent immobility. Characteristic linear relationships were then apparent between age and the activities of serum aldolase (Fig. 4), of SGOT (Fig. 5), and of SGPT (Fig. 6).

LIMB-GIRDLE MUSCULAR DYSTROPHY This was studied in a pregnant woman and in an advanced case.

Normal twin pregnancy, labour, and puerperium during early limb-girdle dystrophy A pregnant woman, aged 24 years, with early limb-girdle muscular dystrophy showing primary involvement of the pelvic girdle was admitted to the maternity hospital. An older sister had an exactly similar progressive muscular weakness; there was no other family history.

Examination disclosed a normal twin pregnancy near term. Not long after discharge under observation she was re-admitted, and 24 hours later was delivered of viable non-identical twin daughters after a vigorous normal labour.

Serum enzyme assays (Figs. 7 and 8) were continued from her first appearance and admission, through labour, delivery, and the puerperium, and for many weeks thereafter. Cord and later fontanelle blood was obtained from each twin (Table IV).

After an uneventful puerperium, she felt her limbs weaker than before, in contrast to a report of normal pregnancy and delivery during dystrophia myotonica (Davis, 1958).

Comparative obstetric studies in healthy women Figure 9 illustrates the labour and early puerperium of a healthy woman delivered of viable non-identical twin sons. Indifferent labour due to uterine incoordination required final strenuous fundal compression. There was no other difficulty.

Figure 10 shows a closer study in a healthy multiparous woman delivered of a viable son and daughter. Manual removal disclosed the second placenta one third infarcted, here bearing the attachment of a small macerated foetus compressus. Otherwise delivery was normal.

Effects of rest and exercise in advanced limb-girdle dystrophy A 19-year-old youth had recently noticed increasing weakness of the upper arms and shoulders, and frequent falls due to unsteadiness progressing over several years. On examination he showed typical limbgirdle muscular dystrophy far advanced in both pelvic and shoulder girdles. There was no family history.

He was advised to exercise; 48 days later he was admitted and exercised under supervision for 17 days, then put to bed for six days, allowed up for two days and kept in bed again for a week. Thereafter he was allowed up until discharged. Serum enzyme assays were 
Sources of error in the biochemical diagnosis of muscular dystrophy

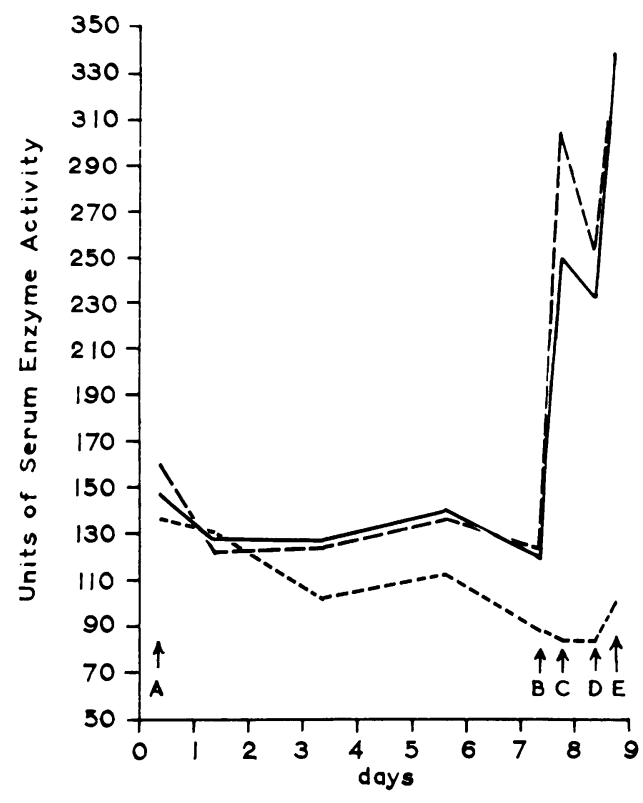

FIG. 1. Early dystrophy.

FIGS. 1, 2, and 3. Effects of rest and exercise in ambulant patients with the Duchenne type of dystrophy. A, on admission before being put to bed; $\mathrm{B}$ and $\mathrm{C}$, on morning and evening of the first day out of bed; $\mathrm{D}$ and $\mathrm{E}$, on morning and evening of the second day out of bed.

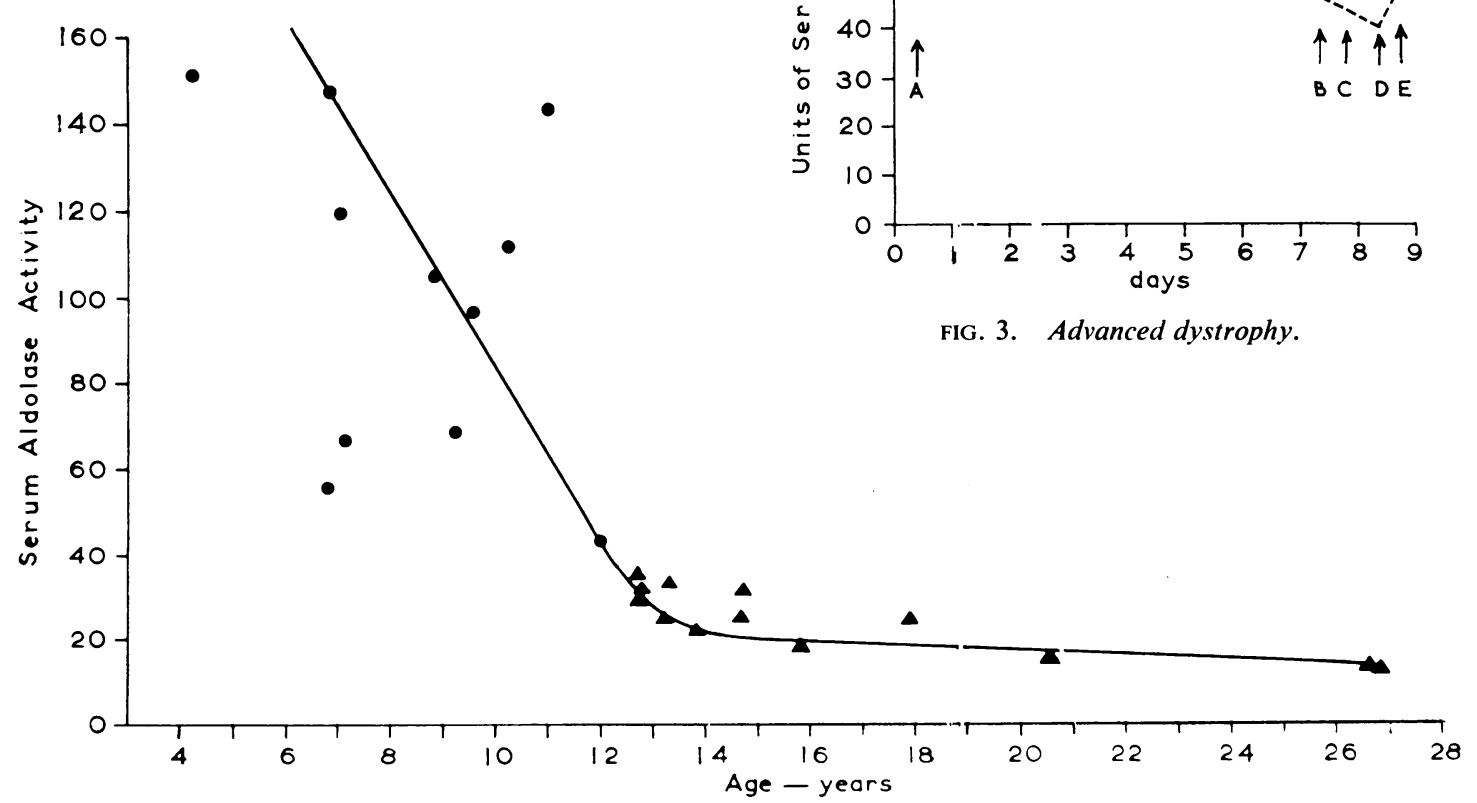

FIG. 4. Exact age and serum aldolase activity in patients with the Duchenne type of dystrophy.

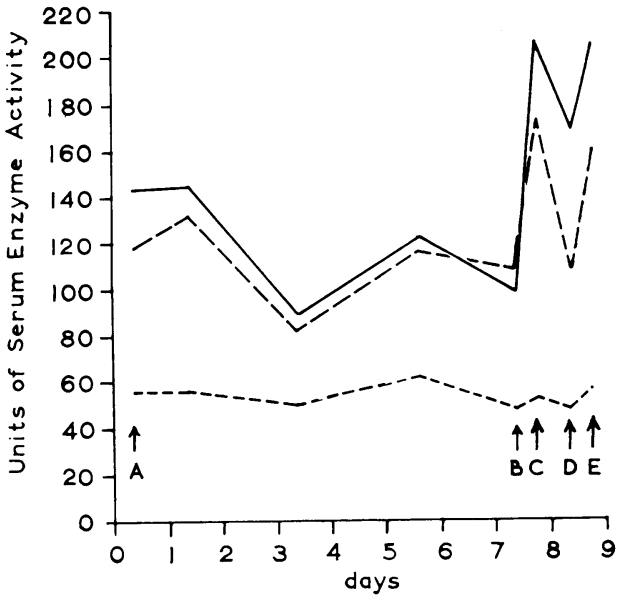

FIG. 2. Moderately advanced dystrophy.

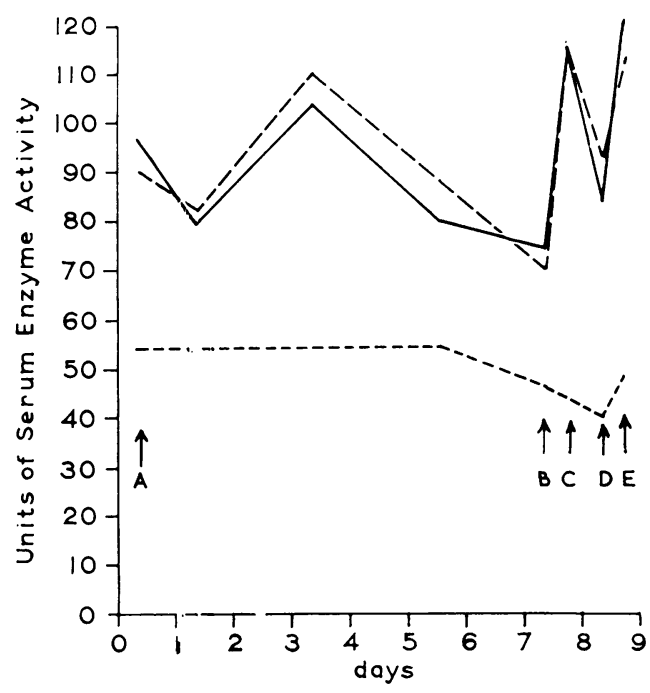

这余 


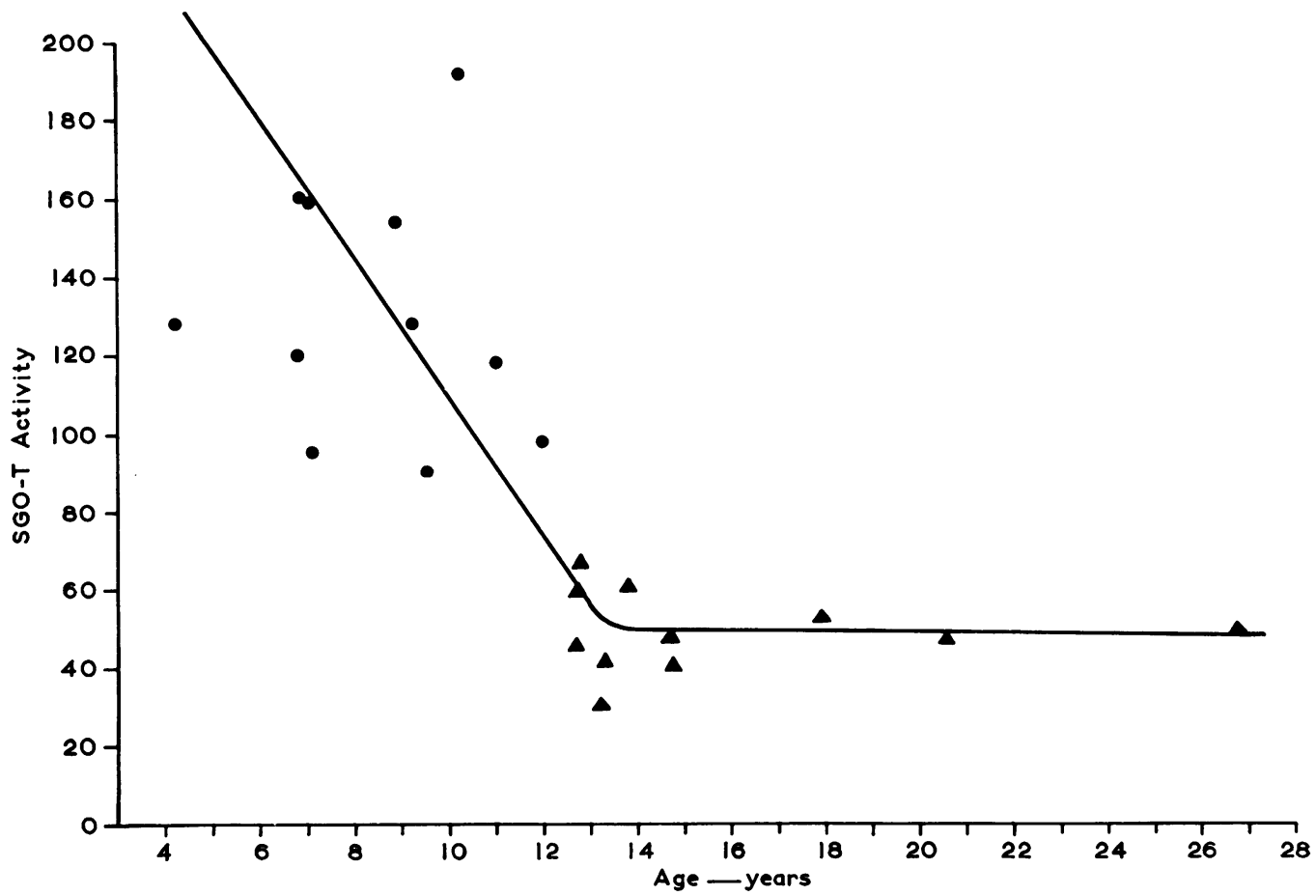

FIG. 5. Exact age and SGOT activity in patients with the Duchenne type of dystrophy.

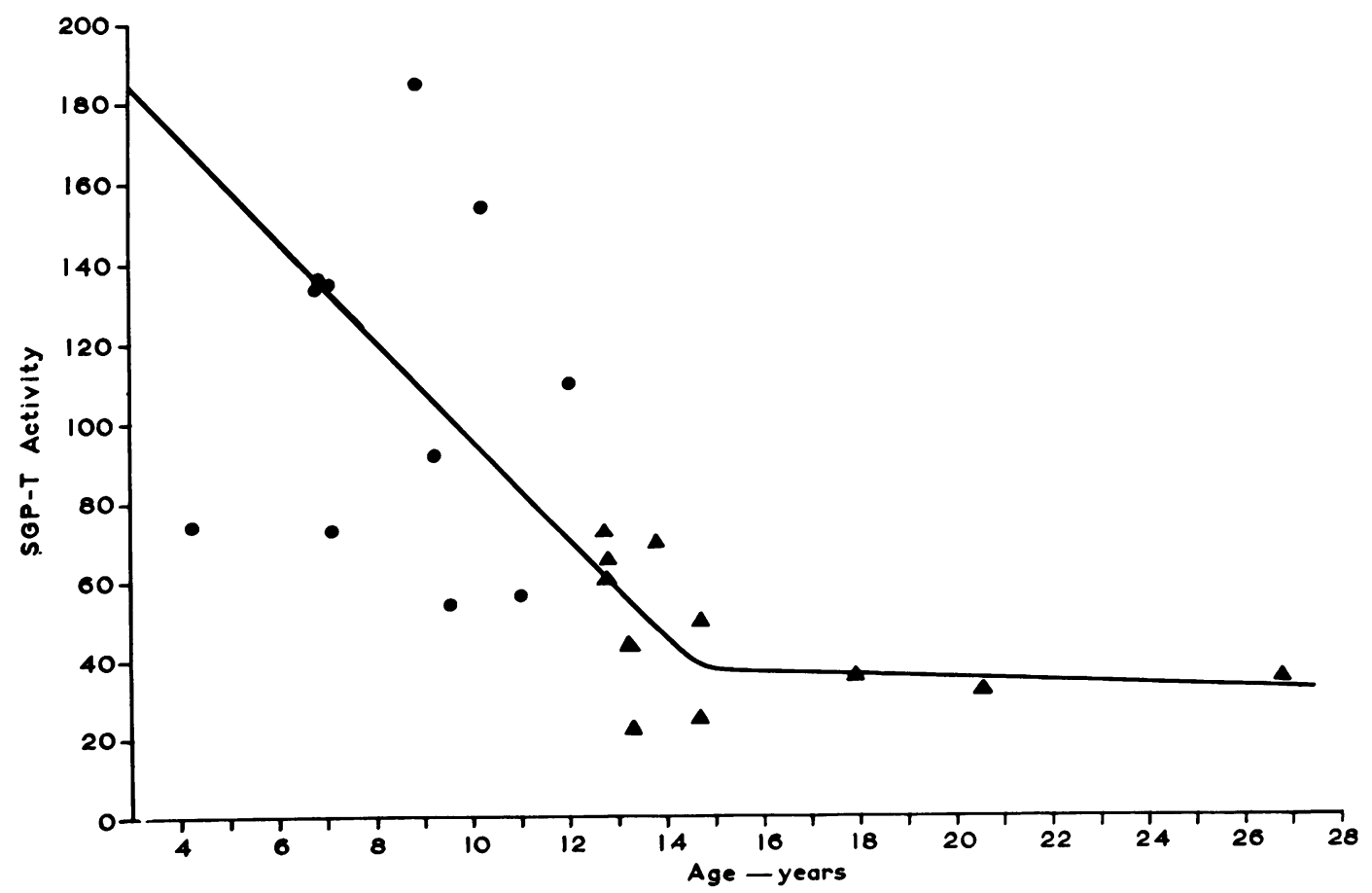

FIG. 6. Exact age and SGPT activity in patients with the Duchenne type of dystrophy. 


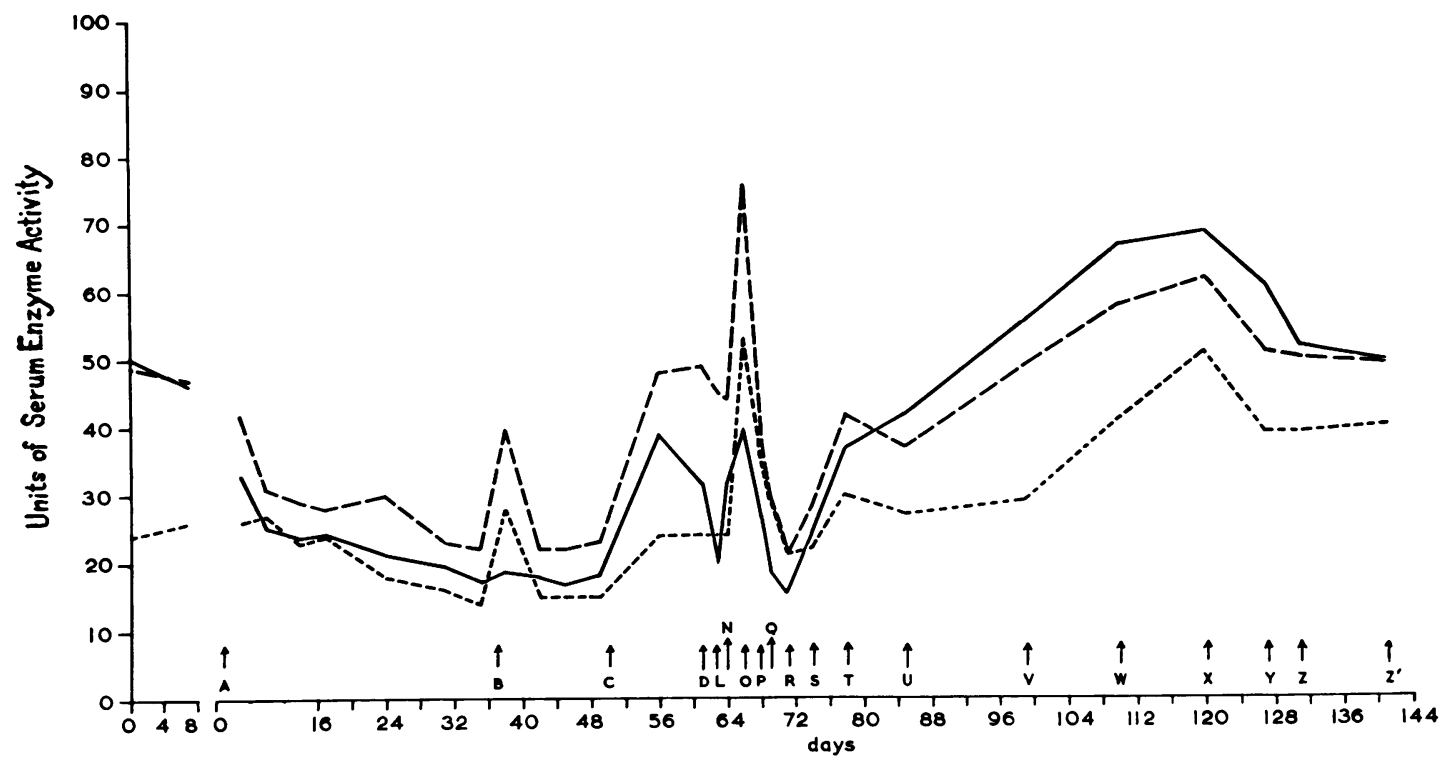

FIG. 7. Late pregnancy, delivery, and the puerperium.

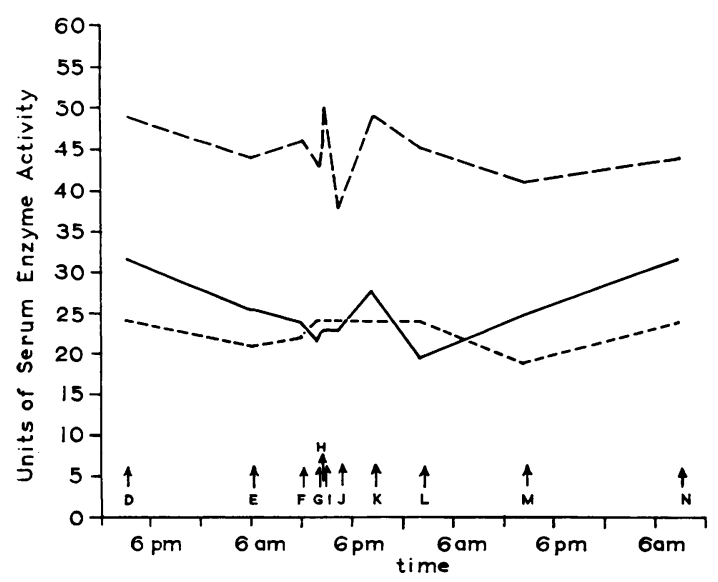

FIG. 8. The course of labour and delivery.

A, on admission to bed for preliminary assessment; $\mathrm{B}$, active physiotherapy for 30 minutes; $\mathrm{C}$, on first discharge home under observation; $\mathrm{D}$, admission to bed in early labour; E, eight hours before first birth; F, two hours before first birth in strong labour; G, during uterine relaxation between deliveries. On venepuncture after delivery of placentae: $\mathrm{H}$, immediately afterwards, uterus firmly contracted; I, 15 minutes; J, two hours; K, six hours; $L, 12$ hours; M, 24 hours; N, 42 hours; 0,91 hours afterwards. $\mathrm{P}, \mathrm{Q}, \mathrm{R}$, in bed after delivery before discharge home at $\mathrm{R} ; \mathrm{S}$, first venepuncture at home; T, 30 minutes after first short walk out of doors; $\mathrm{U}$ to $\mathrm{Z}$, remainder of venepunctures at home.

FIGS. 7 and 8. Normal twin pregnancy during early limb-girdle dystrophy. 


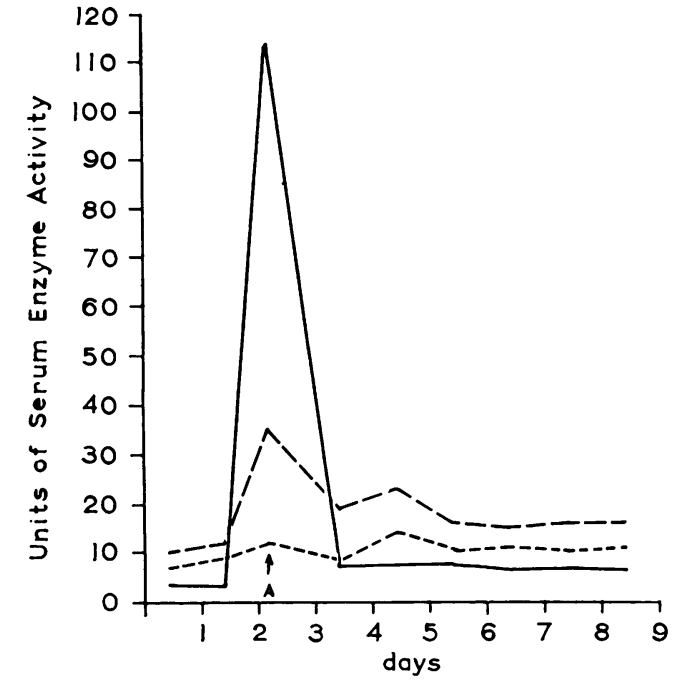

FIG. 9. Twin delivery from healthy mother with manual uterine compression.

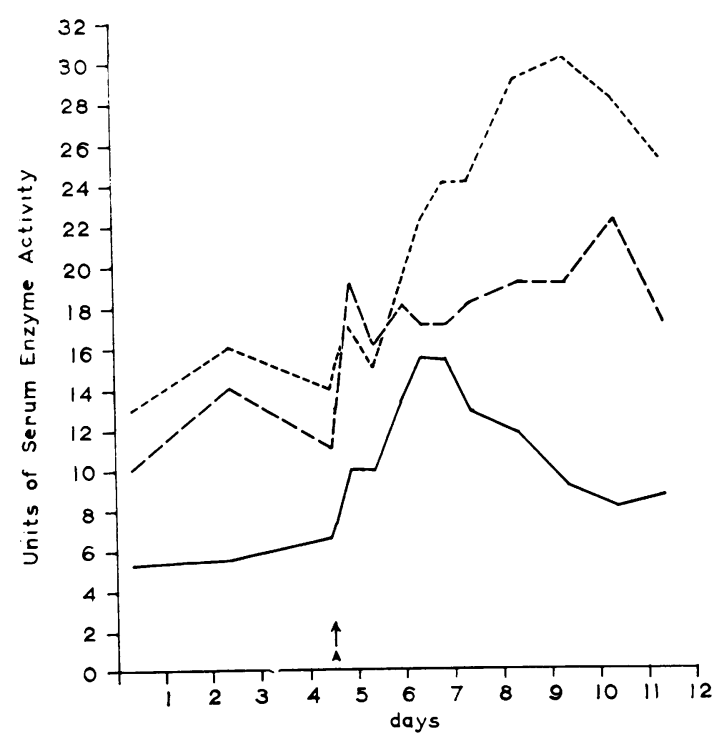

FIG. 10. Twin delivery from healthy mother with manual removal of placentae and foetus compressus. continued throughout as described in the legend to Figure 11.

THE MYOTONIC SYNDROME One representative case is described and results in others are tabulated.

Effects of rest and exercise in severe myotonia congenita A 20-year-old road labourer had life-long muscular stiffness aggravated by cold and relieved by repeated movement.

On examination he showed no wasting but instead great muscular development and power, with pronounced myotonia on contraction or percussion of muscle, attenuated by repeated movement. Lens opacities and frontal baldness were absent; he has since married and is a father. A diagnosis was made of severe myotonia congenita with no suggestion of dystrophia myotonica.

Seventeen days after admission to hospital he was put to bed for six days, then allowed up for two days, then kept in bed again for a week with daily injections of A.C.T.H., which appeared to abolish the myotonia. Adrenocorticotrophic hormone was continued for two days of ambulation; three days later he was discharged, and after eight days myotonia recurred. He obtained light employment for the rest of the investigation. Serum enzyme assays were continued throughout as described in the legend to Figure 12.

Casual venepuncture in other cases of myotonia congenita Table I lists the results. Four patients had generalized hypertrophy without weakness or wasting, $\overrightarrow{\mathbb{D}}$ and were in light occupations. A fifth had widespread? paramyotonia congenita. All but one, to whom they wereo not given, found procaine amide tablets beneficial.

ADDITIONAL INVESTIGATIONS Further useful information was obtained in other conditions.

Neurogenic muscular wasting Table II shows norma findings in five patients with neurogenic weakness.

The polymyositis syndrome Table III shows the results in five patients with myositis. Three were mildly disabled by proved chronic polymyositis with periodic painful exacerbations. A fourth was badly disabled for seven months by acute polymyositis, proved at biopsy, chiefly of the upper arms and shoulder girdle; ten months later steroid therapy restored full activity.

The fifth, a youth of 16 years, developed acute painful myositis of all four limbs concomitant with overwhelming staphylococcal septicaemia after a trivial injury. The serum enzyme assays (Table III) cover three weeks of massive antibiotic, antitoxin, and steroid therapy from the initial desperate illness to complete recovery with slight residual muscle wasting.

Serum enzyme activities in close relatives of dystrophic patients Table IV concerns the patient and the twin daughters she bore during early limb-girdle dystrophy.

Table V deals with a 4-year-old boy with the Duchenne type of dystrophy, his healthy mother again pregnant, and his infant brother 17 days after birth from that pregnancy.

Table VI shows the findings in the parents and in both healthy adult brothers of two young men in the terminal stages of the Duchenne type of dystrophy.

Table VII shows the findings in healthy parents and 


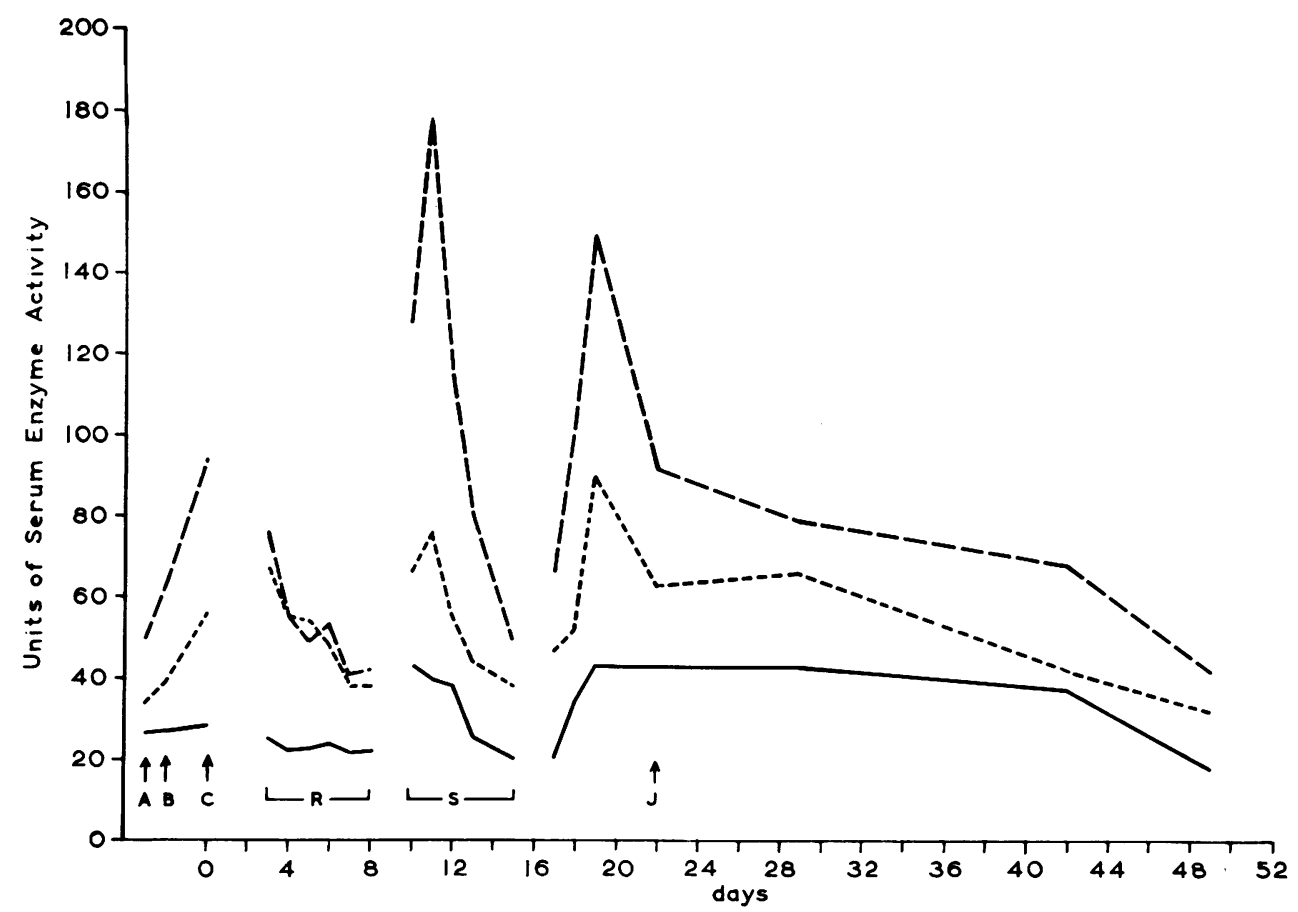

FIG. 11. Effects of rest and exercise in advanced severe limb-girdle dystrophy.

A, on first appearance as an out-patient; B, on admission after 48 days of general exercise; C, after 17 days of systematic exercise in hospital. Period $\mathrm{R}$, first interval of bed rest for six days; period $\mathrm{S}$, second interval of bed rest for seven days; $\mathrm{J}$, on discharge ambulant from hospital.

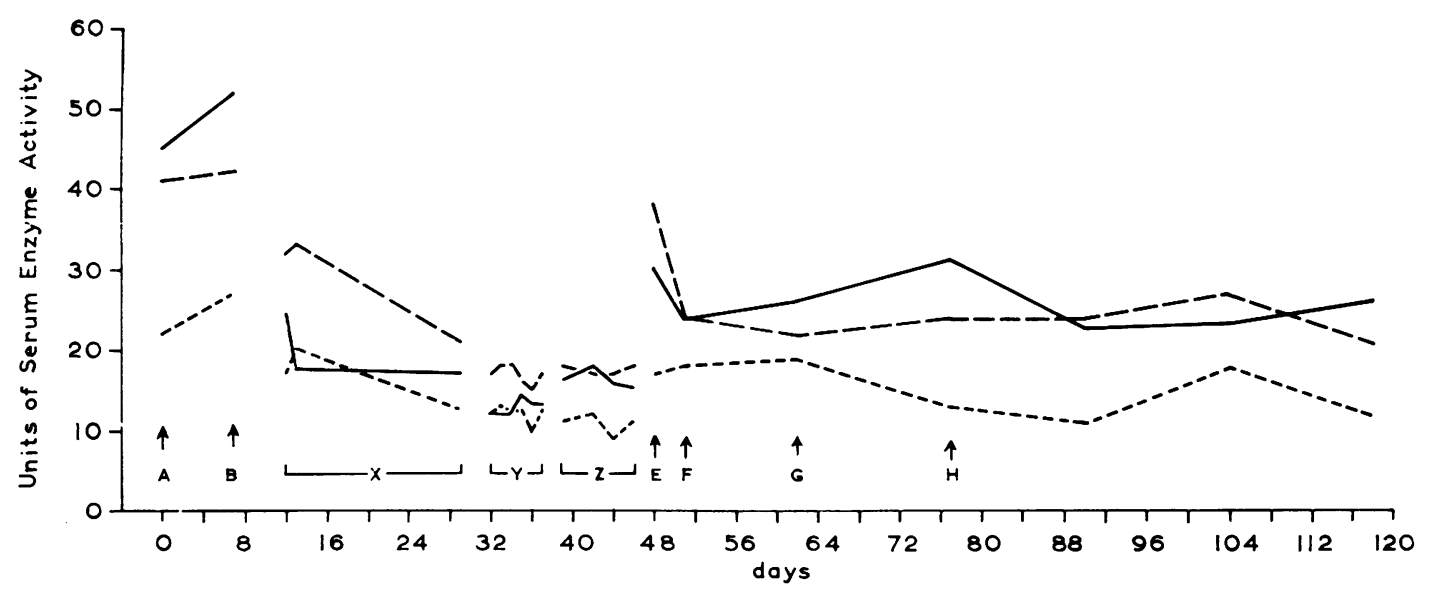

FIG. 12. Effects of rest and exercise in severe myotonia congenita.

$\mathrm{A}$ and $\mathrm{B}$, during heavy employment. Period X, ambulant in hospital for 17 days; period $Y$, first interval of bed rest for six days; period Z, second interval of bed rest for seven days. E, on termination of A.C.T.H. therapy after two days' ambulation; $\mathrm{F}$, on discharge ambulant from hospital; $\mathrm{G}$, at home three days after return of myotonia; $\mathrm{H}$, after 10 days in light employment. 
TABLE I

MYOTONIA CONGENITA

\begin{tabular}{|c|c|c|c|c|c|c|}
\hline \multirow[b]{2}{*}{ Condition } & & \multirow[b]{2}{*}{$\begin{array}{l}\text { SGPT } \\
\text { (units per ml.) }\end{array}$} \\
\hline & Severity & $\begin{array}{l}\text { Age } \\
\text { (yr.) }\end{array}$ & Sex & $\begin{array}{l}\text { Serum Aldolase } \\
\text { (units per ml.) }\end{array}$ & $\begin{array}{l}\text { SGOT } \\
\text { (units per } m l . \text { ) }\end{array}$ & \\
\hline $\begin{array}{l}\text { Myotonia congenita } \\
\text { Myotonia congenita } \\
\text { Myotonia congenita } \\
\text { Myotonia congenita } \\
\text { Paramyotonia congenita }\end{array}$ & $\begin{array}{l}\text { Severe } \\
\text { Moderate } \\
\text { Mild } \\
\text { Mild } \\
\text { Moderate }\end{array}$ & $\begin{array}{l}20 \\
27 \\
33 \\
18 \\
46\end{array}$ & $\begin{array}{l}\mathbf{M} \\
\mathbf{F} \\
\mathbf{M} \\
\mathbf{F} \\
\mathbf{F}\end{array}$ & $\begin{array}{r}26 \cdot 5 \\
19 \cdot 0 \\
7 \cdot 9 \\
6 \cdot 1 \\
10 \cdot 1\end{array}$ & $\begin{array}{l}21 \\
16 \\
14 \\
15 \\
16\end{array}$ & $\begin{array}{l}12 \\
13 \\
19 \\
20 \\
18\end{array}$ \\
\hline
\end{tabular}

TABLE II

Condition

NEUROGENIC MUSCULAR WASTING

\begin{tabular}{lllll} 
Condition & $\begin{array}{l}\text { Age } \\
(y r .)\end{array}$ & Sex & \multicolumn{1}{c}{$\begin{array}{c}\text { Serum Aldolase } \\
\text { (units per ml.) }\end{array}$} & $\begin{array}{c}\text { SGOT } \\
\text { (units per ml.) }\end{array}$ \\
\hline (units per ml.)
\end{tabular}

TABLE III

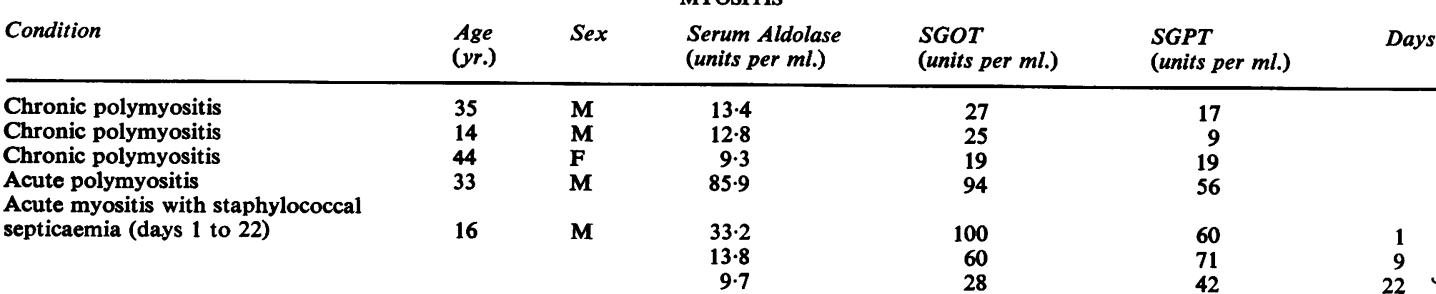

TABLE IV

NON-IDENTICAL TWINS AND MATERNAL LIMB-GIRDLE DYSTROPHY

\begin{tabular}{lr}
$\begin{array}{l}\text { Serum Aldolase } \\
\text { (units per ml.) }\end{array}$ & $\begin{array}{l}\text { SGOT } \\
\text { (units }\end{array}$ \\
\hline $22 \cdot 5$ & 46 \\
$19 \cdot 4$ & 33 \\
16.2 & 20 \\
$29 \cdot 6$ & 41 \\
26.2 & 26
\end{tabular}

TABLE V

INFANT BROTHER OF DUCHENNE-TYPE DYSTROPHIC BOY

\begin{tabular}{lcccc} 
Condition & Age & Sex & \multicolumn{1}{c}{$\begin{array}{c}\text { Serum Aldolase } \\
\text { (units per ml. })\end{array}$} & $\begin{array}{c}\text { SGOT } \\
\text { (units per ml.) }\end{array}$ \\
\hline (units per ml.)
\end{tabular}

TABLE VI

DUCHENNE-TYPE DYSTROPHY IN TWO OF FOUR SONS

\begin{tabular}{|c|c|c|c|c|}
\hline Condition & $\begin{array}{c}\text { Age } \\
(y r .)\end{array}$ & $\begin{array}{l}\text { Serum Aldolase } \\
\text { (units per } \mathrm{ml} . \text { ) }\end{array}$ & $\begin{array}{l}\text { SGOT } \\
\text { (units per ml.) }\end{array}$ & $\begin{array}{l}\text { SGPT } \\
\text { (units per ml.) }\end{array}$ \\
\hline $\begin{array}{l}\text { Healthy mother } \\
\text { Healthy father } \\
\text { Healthy son I } \\
\text { Dystrophic son II } \\
\text { Healthy son III } \\
\text { Dystrophic son IV }\end{array}$ & $\begin{array}{l}27 \\
26 \\
23 \\
20\end{array}$ & $\begin{array}{r}7 \cdot 5 \\
7 \cdot 1 \\
12 \cdot 2 \\
13 \cdot 2 \\
7 \cdot 3 \\
15 \cdot 8\end{array}$ & $\begin{array}{l}19 \\
12 \\
33 \\
50 \\
22 \\
47\end{array}$ & $\begin{array}{l}14 \\
11 \\
22 \\
35 \\
16 \\
32\end{array}$ \\
\hline
\end{tabular}

$\begin{array}{lr}46 & 24 \\ 33 & 9 \\ 20 & 16 \\ 41 & 16\end{array}$

Mother immediately after birth of placentae

Cord blood of twin II

ontanelle blood of twin I at 9 days old

Healthy mother in 32nd week of pregnancy

(units per $m l$.)


TABLE VII

\begin{tabular}{|c|c|c|c|c|c|c|}
\hline \multirow[b]{2}{*}{ Condition } & \multicolumn{3}{|c|}{ DUCHENNE-TYPE DYSTROPHY IN ONE } & \multicolumn{3}{|c|}{ NON-IDENTICAL TWIN } \\
\hline & $\begin{array}{l}\text { Age } \\
\text { (yr.) }\end{array}$ & $\operatorname{Sex}$ & Blood Group & $\begin{array}{l}\text { Serum Aldolase } \\
\text { (units per ml.) }\end{array}$ & $\begin{array}{l}\text { SGOT } \\
\text { (units per ml.) }\end{array}$ & $\begin{array}{l}\text { SGPT } \\
\text { (units per ml.) }\end{array}$ \\
\hline $\begin{array}{l}\text { Healthy mother } \\
\text { Healthy father } \\
\text { Healthy twin I } \\
\text { Dystrophic twin II }\end{array}$ & $\begin{array}{l}50 \\
54 \\
128 \\
128\end{array}$ & $\begin{array}{l}\mathbf{F} \\
\mathbf{M} \\
\mathbf{M} \\
\mathbf{M}\end{array}$ & $\begin{array}{ll}\text { AB } & \mathbf{R h}(\mathrm{D})+\mathrm{ve} \\
\mathbf{O} & \mathbf{R h}(\mathrm{D})+\mathrm{ve} \\
\mathbf{B} & \mathbf{R h}(\mathrm{D})+\mathrm{ve} \\
\mathbf{A} & \mathbf{R h}(\mathrm{D})+\mathrm{ve}\end{array}$ & $\begin{array}{r}4 \cdot 2 \\
6 \cdot 4 \\
12 \cdot 0 \\
29 \cdot 7\end{array}$ & $\begin{array}{l}13 \\
12 \\
17 \\
46\end{array}$ & $\begin{array}{l}14 \\
13 \\
16 \\
73\end{array}$ \\
\hline
\end{tabular}

their only progeny, twin sons aged $12 \frac{3}{4}$ years. One twin was crippled by advanced Duchenne type of dystrophy while the other was perfectly healthy; different blood groups and separate placentae at birth proved them nonidentical. No family history was found.

\section{DISCUSSION}

Recent investigations (Cerretelli, Cantone, Morandini and Mammano, 1959; Richter and Konitzer, 1960; Pearson, 1961b; Schlang, 1961; Casula, Cherchi, and Spinazzola, 1961) show that exercise in health may, depending on its severity, increase the activities of serum aldolase, SGOT, and SGPT to as much as thrice the resting values. In muscular dystrophy it has now been shown that this effect is most striking in proportion to the rapidity of the disease and the amount of muscle left.

The aldolase in normal muscle cells shows continual renewal and removal (Schapira, Kruh, Dreyfus, and Schapira, 1960). Removal by cellular efflux (Zierler, Levy, and Andres, 1953) is greatly increased into the circulation by active stimulation in the intact animal before excision (Zierler, 1958a). The rise in serum activity after exercise is thus explained, and its small degree by the rapid serum clearance of aldolase (Sibley, 1958). Disease increasing muscle efflux and renewal must enhance this effect.

Secondary muscular wasting need not imply increased efflux and renewal. In neurogenic muscular disease serum activities are normal (Table II); only slight temporary elevations follow major motor nerve division (Aronson and Volk, 1957b), none occur in polyarthritic disuse atrophy (Gáspárdy, Kovács, Simon, and Vida, 1959), and even the hyperaldolasaemia from starving muscle in malignant cachexia is much reduced by massive protein therapy (White, 1958).

In primary muscle disease, however, enzyme efflux and serum activities are greatly increased, as in polymyositis (Table III), especially if acute (Evans and Baker, 1957; Siekert and Fleisher, 1956; Pearson, 1957 and 1959; Brumlik, Wachs, Hummel, and Boshes, 1959; Thompson and Vignos, 1959; Schapira and Schapira, 1960). Acute myositis may occur with septicaemia (Barrett and Gresham, 1958);
Table III shows restoration of normal serum activities with successful treatment.

The greatest serum elevations occur (Figs. 4, 5, and 6) in the Duchenne type of dystrophy, where muscle efflux enters the circulation directly, the venous return showing higher aldolase activity than the arterial supply (Dreyfus, Schapira, and Demos, 1958). Further, the hereditary primary myopathy of Bar Harbor 129 mice, which closely resembles the disease in man, likewise shows hyperaldolasaemia (Schapira, Schapira, and Dreyfus, 1957) due to increased muscle efflux (Zierler, 1958b), and greatly accelerated turnover of muscle protein (Simon, Lessell, Gross, and Milhorat, 1958; Kruh, Dreyfus, Schapira, and Gey, 1960) which diminishes by increased synthesis being outstripped by greater loss. In human dystrophy, the increased enzyme efflux is almost certainly replaced with similar rapidity, magnifying the effects of exercise on serum enzyme activities.

DUCHENNE TYPE MUSCULAR DYSTROPHY In the three patients selected serum aldolase and SGOT activities varied together in proportion to the muscle mass remaining, representing efflux by exercise of enzymes accumulated by rest (Figs. 1, 2, and 3). The slight decline on rest followed on ambulation by instant large increases showed great muscle permeability in this most rapidly destructive dystrophy. The activity of SGPT, however, was much less markedly affected. These findings seem independent of enzyme molecular weights, those of aldolase and GPT being similar and thrice that of GOT (Green, Leloir, and Nocito, 1945; Dixon and Webb, 1958). However, skeletal muscle contains abundant aldolase and GOT, but 20 times less GPT than GOT (Sibley and Fleisher, 1954; Wróblewski and LaDue, 1956), and thus in the Duchenne type of dystrophy muscle cell permeability may be grossly non-specific.

Further, serum aldolase activity related to age showed greater efflux earlier than later (Thomson et al., 1960), but gave a curve and not the expected straight line reflecting steady disappearance of muscle; serum transaminases defied delineation. These relationships have now been accurately defined (Figs. 4, 5, and 6) in a much larger series of patients (24). The high values in young, active patients declined steeply through widely scattered 
points, and in older immobilized patients much more slowly through closely coinciding points towards values just above normal. The very sharp change in course coincided with the age by which most patients are confined to wheelchairs. Two different processes were evident; the large irregular variations on exertion while the muscle mass sufficed, and the underlying slow decline with shrinkage once inactivity supervened. Serum aldolase was the most sensitive index, SGOT a little less so, but SGPT least of all; and in the Duchenne type of dystrophy the assays therefore take that order of importance.

These complementary studies suggest that in early cases the difference between serum aldolase or SGOT values before rising and again after a full day of activity would confirm the diagnosis suggested by the morning assay, and indicate for prognosis the extent and severity of muscular involvement.

LIMB-GIRDLE MUSCULAR DYSTROPHY In this less disastrous type, the effects of rest and exercise are less florid and slightly different in character.

After admission to bed, the patient with twin pregnancy showed (Fig. 7) rapid diminution of SGOT and SGPT to normal and serum aldolase to twice instead of six times normal. The rapid rise in all three values after discharge was at once reversed by bed rest in labour, the course of which had little effect on them (Fig. 8). Twelve hours after delivery, however, serum aldolase began to rise, 12 hours later the transaminases, and all three reached a marked peak on the fourth day coincident with maximal uterine involution and its enzyme discharge into serum replete with muscle efflux. In three days this excess was cleared, and on dismissal the lowest values so far were recorded. Thereafter a steady rise continued for some six weeks to values much higher than those obtained originally, followed a fortnight later by restoration of equilibrium between enzyme renewal, efflux, and serum clearance. It is important to note that, although assay was of unquestioned value before admission, it could scarcely have assisted diagnosis at the time of final discharge, while the values six weeks later were consistent with a much more destructive myopathy.

Control studies in two normal twin deliveries showed in the first (Fig. 9) the effects of compression on an effete myometrium. The single very high aldolase peak just after placental delivery (A) completely cleared in 24 hours, and was probably due to sudden expression into the circulation of local extracellular accumulation. Both transaminases remained normal, a slight rise disappearing by the fourth day. In the more normal second labour (Fig. 10) following placental delivery (A) serum aldolase rose to twice normal in two days, returning by the sixth; but SGOT and SGPT took five and six days respectively, and barely exceeded normal. The long-dead foetus compressus could have had no effect on the maternal serum enzyme activities (Mason and Wróblewski, 1957). These findings agree with other reports (Santoni, 1956; Bompiani, 1956; Candura and Lovotti, 1957; Wróblewski, 1958; Dubach and Stamm, 1958; Borglin, 1958; Friedman and Lapan, 1958; Prystowsky, Hellegers, Ranke, Ranke, and Chow, 1959).

The findings in the youth with advanced limbgirdle dystrophy (Fig. 11) so obviously support those in the first patient that little comment is required. He showed much more advanced and extensive muscle loss, however, which explained his lower, less labile serum aldolase activity, and insufficient enzyme accumulations to exceed for as long the final equilibria. Yet his serum transaminase activities were more labile, with far greater excursions; this point will be dealt with later.

Both patients with limb-girdle dystrophy showed in their responses minor differences from the Duchenne type of dystrophy by immediate variations, both on rest and exercise, of all three values, aldolase less than both transaminases. These findings bear no relation to enzyme molecular size or muscle content, but possibly to enzyme molecular shape and the nature of the cell membrane defect through whiche efflux occurs.

MYOTONIA CONGENITA In contrast, the serume enzyme activities here altered only on the physicat demands of continued employment, and not on brief? changes in exertion.

On the day after admitting the road labourer (Fig. 12) straight from work his originally normal SGPT and slightly raised SGOT activities had diminished, that of serum aldolase falling from six times to twice normal. Alternate bed rest and ambulation then caused little change, but transient elevations coincided with intense exertion after A.C.T.H. relieved the myotonia, the return of which had little effect. Light employment later slightly raised serum aldolase activity, but the final values were all much lower than originally, SGOT and SGPT being normal and aldolase only thrice instead of six times normal.

This raised serum aldolase activity supports the proposed inclusion of myotonia congenita as a muscular dystrophy (Maas and Paterson, 1950; Walton and Nattrass, 1954), and the normal transaminases, grossly elevated usually only in rapid muscle destruction, seem to confirm that wasting, if it occurs at all, is minimal and late. Raised serum aldolase activities were also found in one of three other patients with myotonia congenita and in one 
with paramyotonia congenita (Table I), all in light occupations; serum transaminases were again normal.

The diagnostic significance of these enzymes in myopathy is now evident. Serum aldolase was almost always considerably raised; but SGOT and SGPT only in the Duchenne type of dystrophy and in acute myositis with their rapid muscle destruction (Figs. 4, 5, and 6 and Table III), much less so in limb-girdle dystrophy with its slower wasting (Figs. 7 and 11), and normal in myotonia congenita with no wasting at all (Fig. 12 and Table I). Serum aldolase activity is thus a sensitive index of the dystrophic process, precisely delineating progress in the Duchenne type (Fig. 4), while the transaminases seem to mark the accompanying muscle destruction.

SERUM ENZYMES IN DYSTROPHIC FAMILIES Since muscular dystrophy shows familial transmission (Walton and Nattrass, 1954; Blyth and Pugh, 1959), reassurance may be sought in infants and even adults of afflicted families. Certain important and misleading difficulties arise.

Infants Placental impermeability allows the foetus its own serum activities, which in newborn infants normally exceed maternal values. Cord serum aldolase activity may be 20 units per ml., or thrice the maternal value (Friedman and Lapan, 1958; Lapan and Friedman, 1959), rising higher in physiological jaundice (Martoni and Musiani, 1958) and grossly in icterus gravis (Sibley and Fleisher, 1954). Much lower values by the third week of life become adult by the sixth month (Beckmann, 1959). Similarly cord and neonatal SGOT activity shows a wide normal range of 13 to 105 units per ml. (Kove, Goldstein, and Wróblewski, 1957a; Prystowsky et al., 1959), and SGPT an upper normal limit of 90 units per ml. (Kove et al., 1957b).

Pearson (1961a), however, found far greater elevations in a 4-month-old boy without clinical signs, but with an extensive family history of the Duchenne type of dystrophy, in whom muscle biopsy later confirmed its presence. The 4-year-old boy reported here (Table V) had obvious signs and gross elevations, while his healthy mother, near term with a second pregnancy, had normal values (Evans and Baker, 1957; White, 1959; Leyburn, Thomson, and Walton, 1961) save for a trivial elevation of aldolase. His 17-day-old infant brother and only sib had values normal for that age, and thus no evidence of dystrophy.

The non-identical twins born during maternal limb-girdle dystrophy (Table IV) also showed, as expected, no evidence of dystrophy, with normal neonatal serum enzyme activities, different from those of the mother, rising predictably with physio- logical jaundice. Two years later they were perfectly healthy.

Older individuals Few cases of twins with the Duchenne type of dystrophy are recorded (Soltan, 1959). The 123-year-old dystrophic boy (Table VII) showed all three expected elevations (Figs. 4, 5, and 6 ), while his healthy non-identical twin showed normal transaminases but a significantly raised aldolase value. Similarly, persistent moderate elevation of serum aldolase activity was found in one of two healthy adult brothers of two patients with terminal Duchenne type of dystrophy (Table VI).

These findings accord with a report (Chung, Morton, and Peters, 1960) that in families exhibiting the Duchenne type of dystrophy a few heterozygous individuals may show increased serum aldolase activities, and, more rarely, some physical disability and creatinuria as well.

From the foregoing instances and discussion, it is clear that enzyme assays in relatives must be interpreted with caution, since modest elevations may occur in health; gross elevations, however, leave no room for doubt, and here the clinical evidence, except in infants, will be obvious.

\section{SUMMARY AND CONCLUSIONS}

The importance of serum aldolase, SGOT, and SGPT activities in the diagnosis of primary muscle disease has been emphasized, and common causes of misleading variations in them have been systematically explored. The following conclusions have been reached:-

1 In neurogenic muscular weakness and wasting all three activities are normal.

2 In the physiological muscle destruction of the early puerperium all three activities show transient elevations.

3 All three activities are raised in myositis, more grossly in the acute than in the chronic form, and are restored to normal after successful treatment.

4 In muscular dystrophy the activities are raised; there is an equilibrium between intracellular enzyme renewal, efflux, and serum clearance. Further:-

$a$ This equilibrium is altered by rest, which causes lessened efflux, diminished serum activities, and intracellular enzyme accumulation, and by subsequent exercise discharging the accumulations to give even greater serum elevations than before.

$b$ Both the original elevations and the magnitudes of their alterations are proportional to the mass of muscle remaining and to the rapidity of its destruction; and both are thus greater in early than in evident Duchenne type of dystrophy, less in limbgirdle dystrophy, and least in myotonia congenita. 
c These alterations differ in character in the Duchenne type of dystrophy from those in limbgirdle dystrophy.

d Physical immobility, as in late Duchenne type of dystrophy, causes these alterations to disappear.

$e$ In ambulant patients with the Duchenne type of dystrophy these alterations are proposed as the basis for a diagnostic and prognostic test.

5 Serum aldolase activity is the most sensitive index of the myopathic process itself, especially in Duchenne type of dystrophy. Elevated activity in some cases of myotonia congenita supports its classification as a muscular dystrophy.

6 The activities of SGOT and SGPT, especially of the former, indicate the rate of muscle destruction in primary muscle disease.

7 Normal neonatal serum activities of all three enzymes are higher than in healthy adults.

8 The healthy brothers of patients with the Duchenne type of dystrophy may themselves show significantly raised serum aldolase activity.

The author wishes to thank Dr. John B. Gaylor for introducing both the patients with limb-girdle dystrophy and Dr. E. B. Hendry, of Glasgow Western Infirmary, for his encouragement, Professor Ian Donald and Dr. James Willocks, of Glasgow Royal Maternity Hospital, and Emeritus Professor Stanley Graham, Dr. R. A. Shanks, and Dr. W. J. Bassett, of the Royal Hospital for Sick Children, for their cooperation, and Mr. John G. Henderson, late secretary of the Glasgow Branch of the Muscular Dystrophy Group. The diagrams were prepared by Miss K. J. Graham of the Department of Medical Illustration, Glasgow Western Infirmary.

\section{REFERENCES}

Aronson, S. M. (1960). Pediat. Clin. N. Amer., 7, 527.

-, and Volk, B. W. (1956). A.M.A. Arch. Neurol. Psychiat., 75, 568. $\longrightarrow$ (1957a). Amer. J. Med., 22, 414.

- (1957b). Proc. Soc. exp. Biol. (N.Y.), 94, 360

Barrett, A. M., and Gresham, G. A. (1958). Lancet, 1, 347.

Beckmann, R. (1956). Klin. Wschr., 34, 1237.

- (1959). Mschr. Kinderheilk., 107, 258.

Beisenherz, G., Boltze, H. J., Bücher, Th., Czok, R., Garbade, K. H., Meyer-Arendt, E., and Pfleiderer, G. (1953). Z. Naturforsch., 8B, 555.

Blyth, H., and Pugh, R. J. (1959). Ann. hum. Genet., 23, 127.

Bompiani, A. (1956). Ann. Ostet. Ginec., 78, 705.

Borglin, N. E. (1958). J. clin. Endocr., 18, 872 and 878.

Breton, A., Gaudier, B., Traisnel, M., and Ponté, C. (1959). Presse méd., 67, 2329.

Brumlik, J., Wachs, H., Hummel, W., and Boshes, B. (1959). Quart. Bull. Northw. Univ. med. Sch., 33, 22.

Bruns, F. (1954). Biochem. $Z,, 325,156$.

Candura, F. and Lovotti, A. (1957). Riv. Ostet. Ginec. prat., 39, 3.

Casula, D., Cherchi, P., and Spinazzola, A. (1961). G. Clin. med., 42, 499.

Cerretelli, P., Cantone, A., Morandini, M. L., and Mammano, R. (1959). Boll. Soc. ital. Biol. sper., 35, 1935.

Chung, C. S., Morton, N. E., and Peters, H. A. (1960). Amer. J. hum. Genet., 12, 52.

Davis, H. A. (1958). J. Obstet. Gynaec. Brit. Emp., 65, 479.

Dixon, M., and Webb, E. C. (1958). Enzymes. Longmans Green, London.
Dreyfus, J-C., and Schapira, G. (1955). C.R. Soc. Biol. (Paris), 149, 1934.

-, and Demos, J. (1958). Clin. chim. Acta, 3, 571

Dubach, U. C., and Stamm, H. O. (1958). Arch. Gynäk., 190, 394.

Evans, J. H., and Baker, R. W. R. (1957). Brain, 80, 557.

Friedman, M. M., and Lapan, B. (1958). J. Lab. clin. Med., 51, 745.

Gáspárdy, G., Kovács, L., Simon, M., and Vida, M. (1959). Z. Rheumaforsch., 18, 455.

Gentili, C. (1959). Clin. pediat. (Bologna), 41, 736.

Green, D. E., Leloir, L. F., and Nocito, V. (1945). J. biol. Chem., $161,559$.

Jacob, W., and Neuhaus, J. (1954). Klin. Wschr., 32, 923.

Kaeser, H. E. (1959). Dtsch. Z. Nervenheilk., 179, 353.

- (1960). Ann. paediat. (Basel), 195, 1.

Karmen, A. (1955). J. clin. Invest., 34, 131.

- Wróblewski, F., and LaDue, J. S. (1955). Ibid., 34, 126

Kove, S., Goldstein, S., and Wróblewski, F. (1957). Pediatrics, 20, 584 (a) and 590 (b).

Kruh, J., Dreyfus, J-C., Schapira, G., and Gey, G. O. (1960). J. clin. Invest., 39, 1180.

Lapan, B., and Friedman, M. M. (1959). J. Lab. clin. Med., 54, 417.

Leyburn, P., Thomson, W. H. S., and Walton, J. N. (1961). Ann. hum. Genet., 25, 41.

Maas, O., and Paterson, A. S. (1950). Brain, 73, 318.

Martoni, L., and Musiani, S. (1958). Clin. pediat. (Bologna), 40, 397.

Mason, J. H., and Wróblewski, F. (1957). A.M.A. Arch. intern. Med., 99, 245.

Murphy, E. G., and Cherniak, M. M. (1958). Pediatrics, 22, 1110.

Pearson, C. M. (1957). New Engl. J. Med., 256, 1069.

(1959). Arthr. and Rheum., 2, 127.

- (1961a). Lancet, 1, 276.

(1961b). Personal communication.

Prystowsky, H., Hellegers, A. E., Ranke, E., Ranke, B., and Chow, B. F. (1959). Amer. J. Obstet. Gynec., 77, 1.

Reitman, S. and Frankel, S. (1957). Amer. J. clin. Path., 28, 56.

Richter, K. and Konitzer, K. (1960). Klin. Wschr., 38, 998.

Rowell, N. R., and Smith, A. J. (1959). Brit. med. J., 2, 459.

Rowland, L. P., and Ross, G. (1958). A.M.A. Arch. Neurol. Psychiat., $80,157$.

Salvi, G., Ambanelli, U., Rosati, G., Carreras, M., and Mironi, F. (1959). Riv. Pat. nerv. ment., 80, 1.

Santoni, G. (1956). Ann. Ostet. Ginec., 78, 718.

Schapira, F., Demos, J., Schapira, G., and Dreyfus, J-C. (1957). Rev. franc. Etud. clin. biol., 2, 728.

Schapira, G., and Dreyfus, J-C. (1957). C. R. Acad. Sci. (Paris), $245,753$.

Schapira, G., Dreyfus, J-C., and Schapira, F. (1953). Sem. Hôp. Paris, 29, 1917.

—, Kruh, J., Dreyfus, J.-C., and Schapira, F. (1960). J. biol. Chem., 235, 1738.

__, and Schapira, F. (1960). Ann. Biol. clin., 18, 1.

Schlang, H. A. (1961). Amer. J. med. Sci., 242, 338.

Sibley, J. A. (1958). Ann. N.Y. Acad. Sci., 75, 339.

- and Fleisher, G. A. (1954). Proc. Mayo Clin., 29, 591.

(1949). J. biol. Chem., 177, 859.

Siekert, R. G., and Fleisher, G. A. (1956). Proc. Mayo Clin., 31, 459.

Simon, E. J., Lessell, I., Gross, C. S., and Milhorat, A. T. (1958). Fed. Proc., 17, 311.

Slater, E. C. (1953). Biochem. J., 53, 157.

Soltan, H. C. (1959). Acta Genet. med. (Roma), 8, 434.

Thompson, R. A., and Vignos, P. J. (1959). A.M.A. Arch. intern. Med., 103, 551.

Thomson, W. H. S., Leyburn, P., and Walton, J. N. (1960). Brit. med. $J ., 2,1276$.

Walton, J. N. (1956). J. Indian med. Prof., 2, 997.

- and Nattrass, F. J. (1954). Brain, 77, 169.

Whedon, G. D. (1952). Proc. 1 st and 2 nd med. Conf. M.D.A.A., $1951 / 2$, pp. $39-45$.

White, A. A., and Hess, W. C. (1957). Proc. Soc. exp. Biol. (N.Y.), $94,541$.

White, L. P. (1958). Ann. N.Y. Acad. Sci., 75, 349. (1959). Calif. Med., 90, 1

Wróblewski, F. (1958). Advances in Clinical Chemistry, vol. I, p. 342. Academic Press, New York.

- , and LaDue, J. S. (1956). Proc. Soc. exp. Biol. (N. Y.), 91, 569.

Zierler, K. L. (1958a). Ann. N.Y. Acad. Sci., 75, 227.

(1958b). Bull. Johns Hopk. Hosp., 102, 17.

- Levy, R. I., and Andres, R. (1953). Ibid., 92, 7. 